\title{
Association Between Hyperglycemia And Prostate Volume In Patients With Benign Prostate Enlargement : A Hospital Case-Control Study
}

\author{
Eriawan Agung Nugroho ${ }^{1}$, Rickky Kurniawan ${ }^{2} *$ \\ ${ }^{1}$ Sub Division of Urology, Faculty of Medicine Diponegoro University/Dr. Kariadi Hospital, Semarang, \\ Indonesia \\ ${ }^{2}$ Resident of General Surgery, Faculty of Medicine Diponegoro University/Dr. Kariadi Hospital, Semarang, \\ Indonesia
}

\section{Article Info}

History:

Received : 12 Dec 2017

Accepted : 28 Dec 2017

Available: 31 Dec 2017

\begin{abstract}
Introduction: Prostate is a male organ which might enlarge mostly, either benign or malignant. Hyperglycemia is one of the factor that increase the risk of benign prostate hyperplasia. There is lack of studies which assessed the relationship between benign prostate hyperplasia and isolated hyperglycemia. The aim of this study was to evaluate the association between hyperglycemia and prostate volume in patients with benign prostate enlargement in dr. Kariadi Hospital Se marang.

Method: We conducted a retrospective analysis of clinical data which obtained from 640 men between 2010 and 2012 who admitted to the hospital with diagnosis of benign prostate enlargement. By their medical records, these patients were evaluated of their plasma glucose level and prostate volume by trans rectal ultrasound. The presence of hyperglycemia was determined based on the American Diabetes Association (ADA) and the European Association for the Study of Diabetes (EASD). Patients have already been diagnosed with controlled diabetes mellitus by an internist. We allocated the subjects into two groups: patients with hyperglycemia and non-hyperglycemia. Logistic regression analys is was used to assess whether hyperglycemia was associated with the increased risk of benign prostate enlargement.

Results: Significant difference of prostate volume found between groups. Prostate volume was significantly greater in hyperglycemia group compared with nonhyperglycemia ones in all sub-groups based on age (in decades). Odds Ratio (OR) in patients with hyperglycemia was 2.25 (95\% CI: 1.23-4.11). By non-parametric Spearman test it obtained Group $1(\mathrm{P} 1) \mathrm{p}=0.000$ and $\mathrm{r}=0.669$, group 2 (P2) it obtained $p=0.000$ and $r=0.672$, group $3(\mathrm{P} 3)$ it obtained $p=0.000$ and $r=0.415$ which implied strong positive as sociation

Conclusion: Hyperglycemia and prostate volume were significantly associated in patients with benign prostate enlargement. Hyperglycemia became a significant risk factor for prostate enlargement in patients with benign prostate enlarge ment in dr. Kariadi Hospital Se marang.
\end{abstract}

Keywords : hyperglycemia, benign prostate enlargement

\section{INTRODUCTION}

There were some changes in geriatric body tissue which was caused by the degeneration process, mainly body organs, where was no more cell developmental there. Degeneration causes dimin ished function in such organ, including the urinary tract system, leading to various urological disorder or specific urological disease. $^{2}$

Bladder and urethral function in elderly affected by physiological aging process in their systems, for example in bladder anatomy which 
* Corresponding author:

Rickky Kurniawan

E-mail: rickkymd@gmail.com

aging characterized by the reducing muscle cells number and it replaced by fatty and connective tis sue. $^{7}$

Prostate is a male organ which might enlarge mostly, either benign or malignant. On benign prostate enlargement or benign prostatic hyperplasia $(\mathrm{BPH})$ the periurethra gland enlarged, while the original prostate tissue compelled to peripheral into the capsule. BPH arise along with age and the etiology of BPH is closely related to degenerating process. 1,10

Several theories existed about the causes of BPH. Currently, the most widely adopted is it correlation with male hormones, especially testosterone. In prostate gland testosterone will be converted to Dehidro- testosteron (DHT). Then, DHT chronically stimulate the prostate gland to enlarge. Prostate enlargement was already apparent at 25 years-old at about $25 \%$. At the age of 80 , nodules seen in $90 \%$ of which $50 \%$ of them were symptomatic. $^{6,8,9}$ BPH patients usually sustained frequent micturition, mainly at night, occasionally it can not be detained. When the pressing on urethra increases, urine discharge will be more difficult and urinary stream weakened till total retention. ${ }^{3,4,5}$

Another factor that affects $\mathrm{BPH}$ were the background characteristics of the patient including age, family history, obesity, increased cholesterol levels, high diet in animal fat, exercise, smoking, alcohol drinking, hyperglycemia and sexual activity. ${ }^{5}$

Several investigators have reported the effect of age which increase BPH incidence, including study by Kojma et al regarding the influence of age and prostate volume on symptom scores, which stated that there was a significant relationship between $\mathrm{BPH}$ with age $(p<0.0001){ }^{4}$ Obesity was thought to increase the risk of $\mathrm{BPH}$, according to study of Lee, Body Mass Index BMI) was not associated with symptoms, instead of abdominal circumference and waist to hip ratio (WHR) which implied abdominal obesity might increases the risk. ${ }^{3}$

Studies assessed the relationship between benign prostate hyperplasia with isolated hyperglycemia was lacking. This study will enrich information on risk factors of $\mathrm{BPH}$, primarily its relation to hyperglycemia.

\section{MATERIALS AND METHODS}

This study utilized data from medical record of BPH patients who had been admitted to dr.Kariadi Hospital. Inclusion criteria were hospitalized patients in dr. Kariadi Hospital whom clinically diagnosed of prostate enlargement and underwent trans rectal ultra sound ultrasound examination. Patients with prostate malignancy were excluded from this study.

Then, patients categorized into three age groups of 30-40 years, 40-50 years, and 50-60 years. Normality test was performed if the data was abnormal. Then non-parametric Spearman test was obtained to see the associaten between the variable.

All participants were divided into two groups; case group were clinically-diagnosed BPH patients and laboratory-confirmed of hyperglycemia and recorded in the medical record, while control group were clinically- diagnosed BPH patients and laboratoryconfirmed of non-hyperglycemia and recorded in the medical record. Patients have already been diagnosed with controlled diabetes mellitus by an internist.

Sample size calculation in various OR value was based on the largest sample calculation results, as the minimum sample in this study of 52 samples. The current study recruited 640 samples.

Once the data collected, it was processed and the results presented in tables and boxplot. Data normality and homogeneity were tested by Kolmogorov normality test. Correlation between hyperglycemia and prostate volume conducted by Spearman correlation test.

Differences were considered significant if $\mathrm{P} \leq 0.05$ with $95 \%$ confidence interval. Data analysis was performed with SPSS software Ver. 15.0. for Windows.

\section{RES ULTS}

We performed a retrospective analysis of clinical data from 640 participants between 2010 and 2012 who admitted to hospital with diagnosis of benign prostate enlargement. These patients were evaluated through medical records that include plasma glucose level and prostate volume by transrectal ultrasound.

Group 1 (P1) consist of 153 patients. After normality test performed the data was abnormal. By non-parametric Spearman test it obtained $\mathrm{p}=0.000$ and $r=0.669$ which implied strong positive as sociation.

Table 1. Spearman correlation between prostate volume and plasma glucose level

\begin{tabular}{cccc}
\hline Variables & Mean \pm SD & $\mathrm{p}$ & $\mathrm{r}$ \\
\hline Prostat volume & $42,53 \pm 13,890$ & 0,000 & 0,511 \\
Plasma glucose level & $200,70 \pm 104,247$ & & \\
\hline
\end{tabular}


Table 2. Spearman correlation between prostate volume and plasma glucose level according to age group

\begin{tabular}{|c|c|c|c|c|}
\hline $\begin{array}{c}\text { Age group } \\
\text { (year) }\end{array}$ & Variable & Mean $\pm \mathrm{SD}$ & $\mathrm{p}$ & $\mathrm{r}$ \\
\hline \multirow[t]{2}{*}{$30-40$} & Prostat volume & $39,17 \pm 10,667$ & \multirow{2}{*}{0,000} & \multirow{2}{*}{0,669} \\
\hline & Plasma glucose level & $179,68 \pm 78,050$ & & \\
\hline \multirow[t]{2}{*}{$41-50$} & Prostat volume & $42,96 \pm 11,714$ & \multirow{2}{*}{0,000} & \multirow{2}{*}{0,672} \\
\hline & Plasma glucose level & $209,10 \pm 103,277$ & & \\
\hline \multirow[t]{2}{*}{$51-60$} & Prostat volume & $43,94 \pm 16,024$ & \multirow{2}{*}{0,000} & \multirow{2}{*}{0,415} \\
\hline & Plasma glucose level & $206,29 \pm 114,471$ & & \\
\hline
\end{tabular}

Group 2 (P2) consist of 176 patients. After normality test performed the data was abnormal. By non-parametric Spearman test, it obtained $\mathrm{p}=0.000$ and $\mathrm{r}=0.672$ which implied strong positive association.

Group 3 (P3) consist of 311 patients. After normality test performed the data was abnormal. By non-parametric Spearman test it obtained $\mathrm{p}=0.000$ and $\mathrm{r}=0.415$ which implied moderate positive association. From the results of normality test with Shapiro-Wilk test on hyperglycemia and prostate volume variable, it was found the normal data distribution for each group.

\section{DISCUSS ION}

This study demonstrated the increased of prostate volume in male patients with benign prostate enlargement suffering from hyper- glycemia. Men with a history of hyper- glycemia have greater risk of developing BPH compared with them with no history of hyperglycemia.

Men with plasma glucose levels $>110 \mathrm{mg} / \mathrm{dL}$ had three-fold greater risk of $\mathrm{BPH}$, whereas men with Diabetes Mellitus have twice risk of $\mathrm{BPH}$ compared with healthy men. Previous results found Odds Ratio (OR) in patients with hyperglycemia was $2.25(95 \%$ CI: 1.23-4.11).

Hyperglycemia which was part of the Metabolic Syndrome (MS) has been known as a risk factor for coronary heart disease. Major pathophysiology of hyperglycemia was secondary hyperinsulinemia caused by the presence of insulin resistance in tissues, which stimulates the autonomic nervous system, particularly sympathetic nervous system, resulting in bladder outlet obstruction. Generally, metabolic component in adults would increase with time.

Several studies shown that components of the metabolic syndrome like hyperglycemia was a risk factor for prostate hyperplasia. In 1998, Hammarsten et al reported an association between MS and prostatic hyperplasia. In their study, prostate enlargement were significantly higher in BPH patients with MS annually rather than in BPH patients without MS.
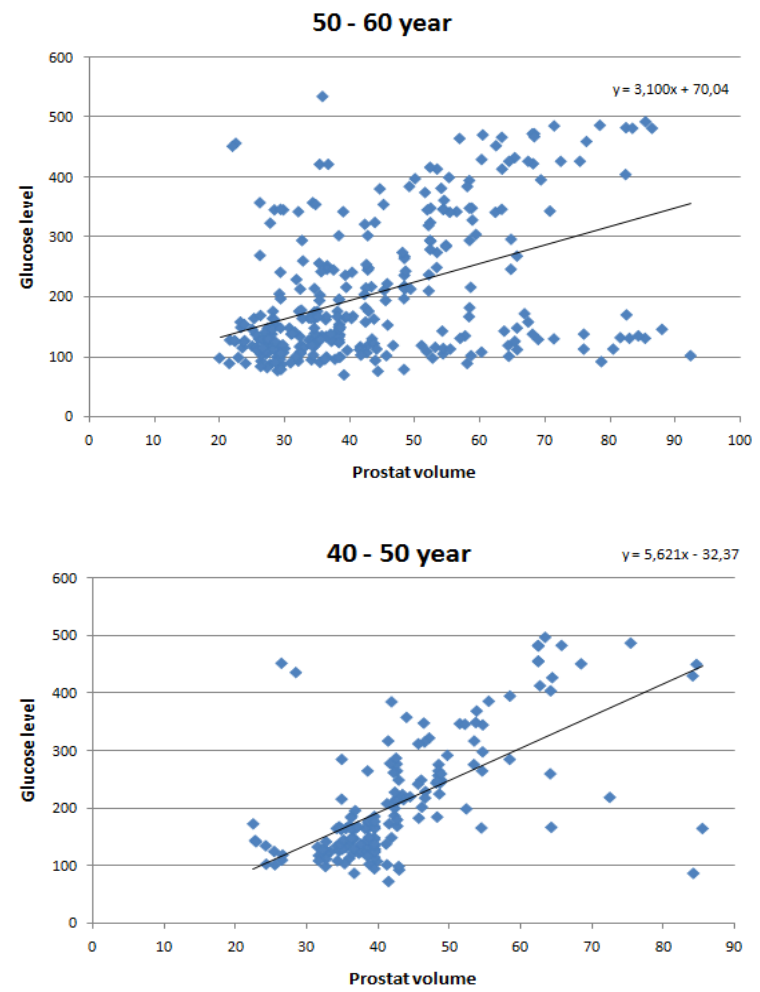

Figure 1.B. Scattered plot of study population age 40-50 y ears old

Ozden et al examined 78 patients with prostatic hyperplasia and lower urinary tract symptoms and concluded that the presence of metabolic syndrome was strongly associated with greater prostate volume and median annual transition zone growth rate. Dahle et al demonstrated that some components of the metabolic syndrome (such as obesity and hyperinsulinemia) were associated with higher risk of prostate hyperplasia. Some studies in Korea also reported that patients with metabolic syndrome tend to have larger pros tate volume.

Parsons et al reported positive relationship between prostate volume with obesity, elevated plasma glucose levels and diabetes. This finding of men suffered from hyperglycemia and obesity has larger prostate size compared with men without this disorder demonstrated that hyperinsulinemia might be associated with the development of BPH, because all 
of these disorders were associated with hyperinsulinemia. Insulin resistance and secondary hyperinsulinemia play role in the relationship between MS and prostate enlargement. As shown in many studies, hyperglycemia and hyperinsulinemia were closely related. Hammrsten et al demonstrated that prostate hyperplasia might be associated with insulin resistance with secondary hyperinsulinemia as a possible ethiologic factor in prostate enlargement.

High insulin levels might induced prostate growth through various mechanisms. Either pathway that explain the increased risk of prostate enlargement in hyperinsulinemia is insulin-like growth factor (IGF) pathway. IGF-1 is a potent mitogen and increase cell proliferation and induces apoptosis in many tissue, including the prostate stroma and epithelium. In line with that, hyperglycemia tends to concomitant with hyperinsulinemia, which increase the insulin-like growth factor, which known as prostate mitogen, and inhibits apoptosis in prostate cascade. These convertion should play a role in the development of prostate tissue. Moreover, condition of hyperinsulinemia increase catecholamine levels in plasma and tissue that lead to a trophic effect on the development of prostate cells by lowering the progression of apoptosis. Thus explanation providing a concept of the relationship between hyperinsulinemia with an enlarged prostate tissue.

In kariadi hospital, no study has ever been done to evaluate the correlation between hyperglycemia and prostate volume in patients with benign prostate enlargement.

\section{ACKNOWLEDGEMENTS}

The author would like to say thank you to management board and staffs Department of Surgery, Medical Faculty, Diponegoro University, Dr. Kariadi Hospital, for the support during the research.

\section{REFERENCES}

1. Birowo P, Rahardjo D. Pembesaran Prostat Jinak. Jurnal Kedokteran \& Farmasi Medika. 2002. No 7 tahun ke XXVIII.

2. Dharmojo B, Martono H. Buku Ajar Geriatri (untuk kesehatan usia lanjut). Edisi 2. Jakarta : FKUI. 2000 .

3. Roehborn, Calus G, McConnell, John D. Etiology, Pathophysiology, and Natural History of Benign prostatic hyperplasia. In : Campbell's Urology. 8th ed. W.B. Saunders ; 2002. p. 1297-1330

4. Suwandi Sugandi. Anatomi dan Fisiologi Kelenjar Prostat serta Kontrol Hormonal terhadap Fungsi Prostat. 2007. URL : http://www.urologi.or.id.

5. Tim redaksi Vita Health. Prostat. Jakarta : PT.Gramedia Pustaka Utama ; 2003

6. Walsh, Patrick C. Benign prostatic hyperplasia. In : Campbell's Urology. 6th ed. W.B. Saunders ; 2015. p.1009-1025Kasper JS, Giovannucci E. A meta-analysis of diabetes mellitus and the risk of prostate cancer.
Cancer Epidemiology Biomarkers \& Prevention. 2006;15:2056-2062

7. Hans. (2008). Jumlah Penderita Diabetes Melitus diIndonesia Meningkat. Diakses pada 14 September 2011

dari http://www.nttonlinenews.com/ntt/index.php?view=artic le\&id=1105\%3Ajumlahpenderitadiabetesmelitusdiindon esiameningkat\&option=com_content $\&$ Itemid $=70$

8. AUA practice guidelines committee. AUA guideline on management of benign prostatic hyperplasia (2003). Chapter 1: diagnosis and treatment recommendations. $J$ Urol 170: 530-547, 2003

9. Ozden, John., De la Rossette JJMH, Alivizatos G, Madersbacher S, Nording J, Emberton M, dan Sanz CR. EAU guidelines on benign prostatic Hyperplasia (PPJ). Eur Urol 40: 256-263, 2006

10. Parson., Aruna., F. Olumi., Aria. Diabetes, growth hormone-insuline-like growth factor pathways and association to benigna prostatic hyperplasia. Elsevier. 2011. Volume $82: 261-271$

11. Hammrsten., Wallner, Lauren P., et al. Hyperglycemia, Hyperinsulinemia, Insulin Resistance, and the Risk of BPH/LUTS Severity and Progression Over Time in Community Dwelling Black Men: The Flint Mens Health Study. Elsevier. 2013. Volume 82: 881-886.

12. Dahle., Vikram, Ajit., et al. Insulin-resistance and benign prostatic hyperplasia:The connection. European Journal of Pharmacology. Volume 641:75-81 